\title{
ANALISIS REGRESI LOGISTIK BINER UNTUK MEMPREDIKSI KEPUASAN PENGUNJUNG PADA RUMAH SAKIT UMUM DAERAH MAJENE
}

\author{
Wahidah Alwi ${ }^{\mathrm{i}}$, Ermawati ${ }^{\mathrm{ii}}$, Saddam Husain ${ }^{\mathrm{iii}}$
}

\author{
${ }^{i}$ Prodi Matematika FST, UINAM, Wahidah.alwi@uin-alauddin.ac.id \\ ${ }^{i i}$ Prodi Matematika FST, UINAM, Ermawati@uin-alauddin.ac.id

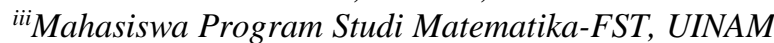

\begin{abstract}
ABSTRAK, Penelitian ini membahas tentang kepuasan pengunjung pada rumah sakit umum daerah Majene. Penelitian ini dilakukan untuk menguji pengaruh tingkat kualitas pelayanan Rumah Sakit Umum Daerah Majene terhadap tingkat kepuasan pasien, dan untuk mengetahui dimensi layanan yang paling mempengaruhi tingkat kepuasan pasien. Adapun metode yang digunakan dalam penelitian ini adalah metode observasi dengan menggunakan kuesioner sedangkan metode penentuan sampel yang digunakan yaitu menggunakan accidental sampling yaitu sebanyak 100 sampel. Sedangkan metode analisis yang digunakan adalah analisis regresi logistik biner. Berdasarkan hasil penelitian menggunakan analisis regresi logistik biner maka diperoleh model terbaik regresi logsistik biner $\ln \left(\frac{\pi(x)}{1-\pi(x)}\right)=-6,892+0,367 \mathrm{X}_{1}-$ $0,127 \mathrm{X}_{2}-0,047 \mathrm{X}_{3}+0,044 \mathrm{X}_{4}+0,403 \mathrm{X}_{5}$. Berdasarkan persamaan regresi logistik biner di atas dapat dilihat bahwa dimensi layanan yang berpengaruh positif serta signifikan terhadap kepuasan pasien adalah variabel tangibles atau bikti fisik $\left(\mathrm{X}_{1}\right)$ dengan nilai koefisien regresi sebesar 0,367 atau $36,7 \%$ dan variabel empathy atau empati $\left(\mathrm{X}_{5}\right)$ dengan nilai koefisien regresi sebesar 0,403 atau 40,3\%. Dari nilai tersebut dapat dilihat bahwa dimensi layanan yang paling berpengaruh terhadap kepuasan pasien pada Rumah Sakit Umum Daerah Majene adalah dimensi layanan empathy atau empati $\left(\mathrm{X}_{5}\right)$ sebesar 0,403 atau 40,3\%.
\end{abstract}

Kata Kunci: Regresi Logistik Biner, Kepuasan Pasien, Dimensi Layanan

\section{PENDAHULUAN}

Seiring dengan perkembangan zaman, Kesehatan seseorang merupakan suatu hak azasi sehingga setiap orang berhakmemperoleh layanan kesehatan secaraadil, merata, dan bermutu. Segala upaya telah ditempuh pemerintah daerah untuk meningkatkan pelayanan kesehatan sehingga masyarakat dapat memperoleh layanan kesehatan yangberkualitas. Salah satu sarana pelayanan kesehatan yang memegang peranan sangat penting adalah rumah sakit. Rumah sakit memiliki peran yang sangat strategis dalam mempercepat peningkatan kualitas kesehatan masyarakat, yang mengakibatkan semakin bertumbuhnya jumlah rumah sakit, serta pengguna jasa dalam hal ini pasien semakin selektif dalam menggunakan fasilitas rumah sakit, hal ini mengakibatkan adanya persaingan dalam industri jasa kesehatan yang semakin ketat dan sulit diprediksikan. Dalam situasi seperti ini menuntut rumah sakit selaku penyedia jasa layanan kesehatan untuk selalu meningkatkan kualitas layanannya.

Mengungkapkan perasaan senang atau kecewa seseorang yang berasal dari perbandingan antara kesan terhadap kinerja (hasil) dari suatu produk atau harapan-harapannya merupakan bentuk dari implementasi kepuasan pelanggan. Pelangganyang sudah merasa puas merupakan aset yang sangat berharga karena jika pelanggan merasa puas maka akan terus melakukan pemakaian terhadap jasa pilihannya, tetapi jika pelanggan tidak merasa puas maka mereka tidak akan menggunakan jasa tersebut dan akan memberitahukan kepada konsumen yang lain dalam hal ini akan menyebabkan kehilangan minat pelanggan untuk berobat pada layanan kesehatan tersebut. Sehingga pelanggan mempunyai pandangan negatif terhadap rumah sakit tersebut, yang mengakibatkan jumlah pelanggan dan keuntungan bagi pihak rumah sakit mengalami penurunan.

Pada masa sekarang ini seiring dengan kemajuan teknologi, rumah sakit yang ada di Indonesia juga ikut berkembang sebagai tempat pelayanan yang memiliki fungsi dasar sebagai tempat penyembuhan kesehatan bagi anggota masyarakat, baik dalam layanan rawat inap, rawat jalan, maupun konsultasi pemeliharaan dan perawatan kesehatan anggota masyarakat. Tanpa kecuali, Rumah Sakit Umum Daerah Majene juga termasuk Rumah Sakit yang terus berkembang dari waktu ke waktu. Perkembangan tersebut tentunya menuntut pihak rumah sakit 
dalam meningkatkan kualitas pelayanan terhadap pasien (Moenir, 2006)

Oleh karena itu, pihak rumah sakit umum daerah majene perlu melakukan analisis untuk mengetahui atau memprediksi kepuasan pengunjung dalam upaya meningkatkan proporsi kepuasan pengunjung. Dalam berbagai bidang ilmu pengetahuan, ilmu statistika semakin menunjukkan perannya dalam memberikan solusi analisis yang mendalam. Salah satu diantaranya analisis regresi logsitik biner.

\section{TINJAUAN PUSTAKA}

\section{Analisis Regresi}

Analisis regresi merupakan salah satu analisis dalam statistik yang digunakan untuk menaksir pola hubungan sebab-akibat antara variabel bebas (dependen) dan variabel respon (independen). Variabel dependen (y) adalah variabel yang nilainya ditentukan oleh variabel lain, sedangkan variabel independen (x) adalah variabel yang nilainya dapat ditentukan secara bebas berdasarkan dugaan bahwa variabel tersebut memiliki pengaruh terhadap variabel dependen. Hubungan antara satu atau dua variabel biasa disebut dengan model regresi. Bentuk umum persamaan analisis regresi diberikan sebagai berikut:

Dimana,

$$
\mathrm{Y}_{i}=\beta_{0}+\beta_{1} \mathrm{X}_{i}+\varepsilon_{i}
$$

$\mathrm{Y}_{i}=$ Variabel terikat untuk pengamatan ke-i

$\beta_{0}=$ Nilai Konstanta

$\beta_{1}=$ Paramater model

$\mathrm{X}_{i}=$ Variabel bebas pengamatan ke-i

$\varepsilon_{i}=$ Galat regresi

Analisis regresi dapat dikelompokkan menjadi dua yaitu analisis regresi linier dan regresi nonlinier. Data hasil penelitian yaitu data berupa data kualitatif dapat dianalisis dengan regresi nonlinier. Salah satu regresi nonlinier yang dapat digunakan untuk menganalisis data kualitatif adalah model regresi logistik (Aisyah, 2010).

\section{Regresi Logistik Biner}

Salah satu bentuk pendekatan model matematis yang dapat digunakan untuk menganalisis hubungan satu atau beberapa variabel prediktor (independent) dengan sebuah variabel respon (dependent) kategori yang bersifat dikotom/binary yaitu Regresi logistik.

Jika variabel responnya terdiri dari dua kategori misalnya $\mathrm{Y}=1$ yang menyatakan hasil yang diperoleh adalah "sukses" dan $\mathrm{Y}=0$ adalah "gagal” maka regresi logisitk tersebut menggunakan regresi logistik biner. Menurut Agresti, bahwa variabel (y) yang demikian lebih tepat dikatakan sebagai variabel indikator dan memenuhi distribusi Bernoulli. Fungsi probabilitas distribusi Bernoulli, yaitu sebagai berikut:

$f\left(y_{i} ; \pi_{i}\right)= \begin{cases}\pi_{i}^{y_{i}}\left(1-\pi_{i}\right)^{1-y_{i}} & \text { untuk } y_{i}=0,1 \\ 0 & \text { untuk } y_{i} \text { yang lain }\end{cases}$ dengan $\pi_{i}=P\left(y_{i}=1\right)$. Dari fungsi distribusi tersebut diperoleh rata-rata:

$$
\begin{aligned}
E(Y) & =1 . P(Y=1)+0 \cdot P(Y=0) \\
& =P(Y=1)
\end{aligned}
$$

Misalkan probabilitas dinotasikan sebagai $\pi(\mathrm{x})$ yang bergantung pada variabel independen $\boldsymbol{x}=$ $\left(\mathrm{X}_{1}, \ldots X_{k}\right)$ dengan $E(y)=\pi$ dan $0 \leq \pi \leq 1$, sehingga diperoleh:

$$
E\left(Y^{2}\right)=1^{2} \pi(x)+0^{2}[1-\pi(x)]=\pi(x)
$$

Dan varians dari $Y$ adalah

$$
V(Y)=E\left(Y^{2}\right)-[E(Y)]^{2}=\pi(x)[1-\pi(x)]
$$

Secara umum, model probabilitas regresi logistik yang melibatkan beberapa variabel independen $x$ dapat dituliskan sebagai berikut:

$\pi(x)=\frac{e^{\beta_{0}+\beta_{1} \mathrm{X}_{1}+\beta_{2} \mathrm{X}_{2}+\cdots+\beta_{k} \mathrm{X}_{k}}}{1+e^{\beta_{0}+\beta_{1} \mathrm{X}_{1}+\beta_{2} \mathrm{X}_{2}+\cdots+\beta_{k} \mathrm{X}_{k}}}$

Model umum regresi logisitk setelah disubtitusikan dengan model logit dari $\pi(x)$ diperoleh:

$$
\begin{aligned}
& \operatorname{Logit} \pi(x)=\ln \left(\frac{\pi(x)}{1-\pi(x)}\right)=\beta_{0}+\beta_{1} \mathrm{X}_{1}+\beta_{2} \mathrm{X}_{2}+ \\
& \cdots+\beta_{k} \mathrm{X}_{k} \text { (Luknis, 2006) }
\end{aligned}
$$

\section{Estimasi Parameter}

Metode Maximum Likelihood Estimation (MLE)dapat digunakan untuk mengestimasi parameter regresi logistik. . Menurut Homser dan Lemeshow (1989) bahwa Metode MLE digunakan untuk mengestimasi parameter- 
parameter dalam regresi logistik yang pada dasarnya metode tersebut memberikan nilai estimasi $\beta$ dengan memaksimumkan fungsi likelihoodnya. Secara matematis fungsi likelihood $\left(x_{i}, y_{i}\right)$ dapat dinyatakan:

$$
f\left(x_{i}\right)=\pi\left(x_{i}\right)^{y_{i}}\left[1-\pi\left(\left(x_{i}\right)\right]^{1-y_{i}}\right.
$$

Apabila setiap pengamatan telah diasumsikan sebagai variable independen maka fungsi likelihoodnya juga merupakan perkalian antara masing-masing fungsi likelihood yaitu sebagai berikut:

$$
L(\beta)=\prod_{i=1}^{n} f\left(x_{i}\right)
$$

\section{Uji Simultan}

Untuk mengetahui signifikansi parameter $\beta$ terhadap variabel dependennya secara keseluruhan menggunakan Uji simultan (serentak). Menurut Homser dan Lemeshow (2000), pengujian parameter model dengan cara serentak dapat menggunakan uji ratio likelihood test dengan statistik uji G, yang dapat digunakan untuk menguji peranan varibel independen dalam model secara bersama-sama. Adapun rumus statistic $\mathrm{G}$ adalah sebagai berikut:

$G=-2 \ln \left[\frac{L_{o}}{L_{p}}\right]$

Keterangan $L_{o}=$ model terdiri dari konstanta saja dan $L_{p}=$ model lengkap (model dengan variabel independen) yang berdistribusi $\chi^{2}$ (Chi-square) dengan derajat bebas banyaknya parameter dalam model $d f=v$.

Hipotesis dari persamaan di atas adalah

$$
\begin{aligned}
H_{0}: & \beta_{1}=\beta_{2}=\ldots=\beta_{p}=0 \quad \text { (Tidak ada } \\
& \text { pengaruh antara variabel independen } \\
& \text { terhadap variabel dependen). } \\
H_{1}: & \text { Minimal terdapat satu } \beta_{j} \neq 0 . \\
& \text { Dengan } j=1,2, \ldots p \text { (Ada pengaruh } \\
& \text { antara variabel independen terhadap } \\
& \text { variabel dependen). }
\end{aligned}
$$

Kriteria ini mengambil taraf nyata $\alpha=0,05$ maka $H_{0}$ ditolak jika nilai $G>\chi_{(\alpha, v)}^{2}$ dimana $v$ adalah banyaknya variabel prediktor (Rinduwan, 2009)

\section{Uji Parsial}

Asuransi berjangka adalah asuransi jiwa Pengujian parameter secara parsial (individu) menggunakan uji Wald, hasil pengujian secara parsial yang dapat menunjukkan apakah suatu variabel independen (prediktor) layak untuk masuk ke dalam model atau tidak.

Hipotesis yang akan diuji adalah:

$H_{0}: \beta_{j}=0$. Dengan $j=1,2, \ldots p \quad$ (Tidak ada pengaruh antara masing-masing variabel independen terhadap variabel dependen).

$H_{1}: \beta_{j} \neq 0$. Dengan $j=1,2, \ldots p$ (Ada pengaruh antara masing-masing variabel independen terhadap variabel dependen).

Menurut Hosmer dan Lemeshow, statistik uji Wald didefenisikan sebagai berikut:

$$
W=\left[\frac{\widehat{\beta}_{i}}{\operatorname{se}\left(\widehat{\beta}_{i}\right)}\right]^{2}
$$

Dengan $\hat{\beta}_{i}$ sebagai penaksir $\beta_{i}$ dan $\operatorname{se}\left(\hat{\beta}_{i}\right)$ sebagai penaksir galat baku $\beta_{i}$. Statistik $W$ menyebar secara normal baku jika $H_{0}$ benar. Keputusan tolak $H_{1}$ diambil ketika $|W|>Z_{\alpha / 2}$ (Edward, 2011).

\section{Uji Kecocokan Model}

Uji kecocokan model digunakan untuk mengevaluasi kecocokan model dengan data, nilai observasi yang diperoleh sama atau mendekati dengan yang diharapkan dalam model. Adapun model yang digunakan harus memenuhi Goodness of Fit (GoF). Suatu model dikategorikan memenuhi GoF jika terdapat kesesuaian antara data yang dimasukkan dalam model dengan data yang diamati. Dalam regresi logistik, metode yang digunakan untuk menguji kelayakan model dapat diukur dengan nilai chisquare dengan uji Homser and Lemeshow. Pengujian ini dapat dilakukan dengan melihat nilai goodness of fit test yang diukur dengan nilai chi-square pada tingkat signifikan 5\%.

Keputusan penerimaan hipotesis didasarkan pada pertimbangan sebagai berikut.

$H_{0}=$ model yang dihipotesiskan fit dengan data; $H_{1}=$ model yang dihipotesiskan tidak fit dengan data (Kusmana, 2014). 


\section{Dimensi Kualitas Layanan}

\section{Wujud Fisik (Tangibles)}

Wujud fisik (Tangibles) merupakan kemampuanperusahaan dalam mewujudukan eksistensinya pada pihak eksternal. Penampilan dan kemampuan sarana dan prasarana fisik perusahaan dengan keadaan lingkungan sekitarnya adalah bukti nyata dari pelayanan yang diberikan oleh pemberi jasa. Yang meliputi fasilitas fisik (gedung dan lain sebagainya), perlengkapan dan perlatan yang digunakan (teknologi), serta penampilan pegawainya

\section{Kehandalan (Reliability)}

Kehandalan (Reliability) merupakan kemampuan perusahaan untuk memberikan pelayanan sesuai yang dijanjikan secara akurat dan terpercaya. Kinerja harus sesuai dengan harapan pelanggan yang berarti ketetapan waktu, pelayanan yang sama untuk semua pelanggan tanpa adanya kesalahan, sikap simpatik dan akurasi yang tinggi.

\section{Daya Tanggap (Responsiveness)}

Daya tanggap (responsiveness) merupakan kemauan untuk membantu dan memberikan pelayanan yang cepat (responsif) dan tepat kepada para pelanggan, dengan menyampaikan informasi yang jelas. Membiarkan konsumen menunggu tanpa ada alasan yang jelas menyebabkan persepsi yang negatif dalam kualitas pelayanan. Pengertian secara singkat adalah keinginan para staf untuk membantu para pelanggan dan memberikan pelayanan dengan tanggap.

\section{Jaminan (Assurance)}

Jaminan (Assurance) merupakan pengetahuan, kesopan santunan, dan kemampuan pegawai dalam suatu perusahaan untuk menumbuhkan rasa percaya kepada para pelanggan terhadap perusahaan tersebut. Yang terdiri dari beberapa komponen yaitu komunikasi (communication), kredibilatas (credibility), keamanan (security), kompeten (competence), dan sopan santun (courtesy).

\section{Empati (Empathy)}

Empati (Empathy)yaitu memberikan perhatian yang tulus dan invidual kepada para pelanggan dengan berupaya memahami keinginan para konsumen. Dimana suatu perusahaan memiliki pengertian dan pengetahuan terkait dengan pelanggan, memahami kebutuhan para pelanggannya secara spesifik serta memilki waktu pengoperasian yang nyaman bagi para pelanggannya (Lupioadi, 2006).

\section{METODOLOGI}

Penelitian ini menggunakan data primer yang bersumber dari responden yang peroleh melalui kuesioner yang disebarkan kepada para responden. Responden yang dimaksud yaitupasien rawat inap pada Rumah Sakit Umum Daerah Majene.

Teknik analisis data yang digunakan dalam penelitian ini adalah regresi logistik biner (binary logistic regression) yang dilakukan secara sistematis melalui beberapa tahapan sebagai berikut:

1. Tabulasi hasil kuesioner.

2. Menaksir parameter model

3. Melakukan uji signifikansi parameter secara simultan dengan menggunakan statistik uji G.

4. Melakukan uji signifikansi parameter secara parsial dengan menggunakan statistik uji Wald untuk mengetahui koefisien paramater yang berpengaruh secara individual terhadap model.

5. Melakukan uji kecocokan model regresi logistik binar diukur dengan nilai chi-square dan uji Hosmer and Lemeshow dengan melihat nilai goodness of fit test yang diukur dengan nilai chi-square pada tingkat signifikan 5\% dengan hipotesis sebagai berikut:

6. Membuat kesimpulan dan interpretasi dengan rasio odds dari model yang telah di uji.

\section{HASIL}

\section{Karakteristik Responden}

Data perkembangan pasien di Rumah Sakit Umu Daerah Majene pada bulan Mei 2017 sebagai berikut: 


\begin{tabular}{|c|c|c|c|}
\hline \multirow{2}{*}{ Bulan } & \multicolumn{2}{|c|}{ Jenis Kelamin } & \multirow{2}{*}{$\begin{array}{c}\text { Jumlah } \\
\text { Pasien }\end{array}$} \\
\cline { 2 - 3 } & $\mathbf{L}$ & $\mathbf{P}$ & 443 \\
\hline Mei & 176 & 267 & 4 \\
\hline
\end{tabular}

Gambar 1 Data Pasien Rumah Sakit

Sumber: Data Sekunder Rumah Sakit Umum Daerah Majene Bulan Mei 2017

Berdasarkan Gambar 1 di atas menunjukkan jumlah pasien Rumah Sakit Umum Daerah Majene pada bulan Mei sebanyak 443 pasien dengan jumlah pasien berjenis kelamin laki-laki sebanyak 176 pasien atau sebanyak 39,73\% dan 267 pasein atau $60,27 \%$ berjenis kelamin perempuan. Deskripstif responden dalam penelitian ini dapat dilihat pada Gambar 2 di bawah ini:

\begin{tabular}{|c|c|c|c|c|c|}
\hline \multirow{2}{*}{ No } & \multirow{2}{*}{ Usia } & \multicolumn{2}{|c|}{ Jenis Kelamin } & \multirow{2}{*}{ Jumlah } & Persentase \\
\cline { 3 - 5 } & $\leq 20$ & 7 & $\mathbf{P}$ & 21 & $21 \%$ \\
\hline 1 & $21-30$ & 21 & 17 & 38 & $38 \%$ \\
\hline 2 & $31-40$ & 10 & 16 & 26 & $26 \%$ \\
\hline 3 & $41-50$ & 5 & 3 & 8 & $8 \%$ \\
\hline 4 & $>50$ & 3 & 4 & 7 & $7 \%$ \\
\hline 5 & 46 & 54 & 100 & $100 \%$ \\
\hline \multicolumn{2}{|c|}{ Jumlah } & $46 \%$ & $54 \%$ & 100 & \multicolumn{2}{c}{} \\
\hline \multicolumn{2}{|c|}{ Persentase } & 46 &
\end{tabular}

Gambar 2 Deskriptif Responden

Dari Gambar 2 di atas menunjukkan bahwa responden terbanyak adalah responden yang berjenis kelamin perempuan dengan jumlah 54 pasien atau 59\%, sedangkan sisanya adalah responden yang berjenis kelamin laki-laki dengan jumlah 46 pasien atau 41\%. Sedangkan ditinjau dari kelompok usia pasien Rumah Sakit Umum Daerah Majene yang paling dominan adalah kelompok usia 21-30 tahun yakni sebesar 38 pasien atau 41\% kemudian diikuti kelompok usia 31- 40 tahun sebesar 26 pasien atau 26\%. Sedangkan kelompok terkecil yaitu pada usia $>$ 50 tahun yakni sebesar 7 pasien atau $7 \%$.

\section{Uji Simultan}

Uji simultan dilakukan untuk mengetahui signifikansi paramameter terhadap model secara serentak (overall). Uji ini menggunakan uji $G$ dengan hipotesis sebagai berikut:

$H_{0}: \beta_{1}=\beta_{2}=\ldots=\beta_{p}=0$ (Tidak ada pengaruh antara variabel independen terhadap variabel dependen).
$H_{1}$ : Minimal terdapat satu $\beta_{j} \neq 0$. Dengan $j=$ $1,2, \ldots p$ (Ada pengaruh antara variabel independen terhadap variabel dependen).

Kriteria ini mengambil taraf nyata $\alpha=0,05$ maka $H_{0}$ ditolak jika nilai $G>\chi_{(\alpha, v)}^{2}$ dimana $v$ adalah banyaknya variabel prediktor

Untuk melihat tingkat variasi data, menggunakan Cox \& Snell R Square seperti Gambar 3 dan hasil perhitungan diperoleh menggunakan program SPSS 16.1, yaitu:

\begin{tabular}{|c|c|c|c|}
\hline Stcp & $\begin{array}{c}-2 \text { Log } \\
\text { likelihood }\end{array}$ & $\begin{array}{c}\text { Cox \& Sncll R } \\
\text { Square }\end{array}$ & $\begin{array}{c}\text { Nagclkcrke } \\
\text { R Square }\end{array}$ \\
\hline 1 & $\mathbf{1 0 6 6 , 8 9 8 8}$ & 0,127 & 0,181 \\
\hline \multicolumn{3}{|c}{ Gambar 3 Model Ringkasan }
\end{tabular}

Estimasi dihentikan pada nomor 10 karena nilai parameter lebih kecil dari 0,001 .

Hasil pada Gambar 3 di atas diperoleh nilai rasio kemungkinan sebesar 106,898. Nilai Chi-square tabel $=11,07$ dengan $\alpha=0,05$ dan $d f=5$, dengan demikian dapat dilihat bahwa, $G \geq \chi_{(\alpha, v)}^{2}$ yaitu $106,898 \geq 11.07$ sehingga $H_{0}$ ditolak, ini berarti bahwa paling sedikit ada satu variabel independen yang berpengaruh secara simultan terhadap variabel dependen pada $\alpha=0,05$. Gambar 3 di atas menunjukkan koefisien determinansi $\left(\mathrm{R}^{2}\right)$ sebesar 0,181 sehingga dikatakan kontribusi variabel independen terhadap variabel dependen adalah sebesar 18,1 $\%$.

\begin{tabular}{|ll|c|c|c|}
\hline & & Chi-Square & df & Sig. \\
\hline Step 1 & Step & 13.533 & 5 & 0,019 \\
& Block & 13.533 & 5 & 0,019 \\
& Model & 13.533 & 5 & 0,019 \\
\hline
\end{tabular}

Gambar 4 Omnibus Dari Model Koefisien

$H_{0}$ ditolak apabila nilai signifikansi pada statistik uji $<\alpha=0,05$. Pada Gambar 4 di atas dapat dilihat bahwa didapatkan nilai signifikansi sebesar 0,019 dimana lebih kecil dari nilai $\alpha=0,05$ dengan kesimpulan $H_{0}$ ditolak yang berarti minimal ada satu variabel bebas yang secara bersama-sama mempengaruhi model.

\section{Uji Parsial}

Uji parsial (individu) dilakukan untuk mengetahui keberartian parameter terhadap 
model. Uji ini menggunakan uji Wald dengan hipotesis sebagai berikut:

$H_{0}: \beta_{j}=0$. Dengan $j=1,2, \ldots p \quad$ (Tidak ada

pengaruh antara masing-masing variabel

independen terhadap variabel dependen).

$H_{1}: \beta_{j} \neq 0$. Dengan $j=1,2, \ldots p$ (Ada pengaruh antara masing-masing variabel independen terhadap variabel dependen).

\begin{tabular}{|l|c|c|c|c|c|c|}
\hline & B & S.E & Wald & Df & Sig. & Exp(B) \\
\hline $\mathrm{X}_{1}$ & 0,367 & 0,156 & 5.546 & 1 & 0,019 & 1,444 \\
$\mathrm{X}_{2}$ & $-0,127$ & 0,106 & 1,448 & 1 & 0,229 & 0,881 \\
$\mathrm{X}_{3}$ & $-0,047$ & 0,099 & 0,227 & 1 & 0,634 & 0,954 \\
$\mathrm{X}_{4}$ & 0,044 & 0,08 & 0,229 & 1 & 0,585 & 1,045 \\
$\mathrm{X}_{5}$ & 0,403 & 0,202 & 3,999 & 1 & 0,046 & 1,497 \\
$\mathrm{C}$ & $-6,892$ & 3,936 & 3,067 & 1 & 0,08 & 0,001 \\
\hline
\end{tabular}

Gambar 5 Variabel Dalam Persamaan

Dengan $\alpha=0,05$ dan $d f=1$ pada Gambar 5 di atas, diperoleh nilai chi-square tabel $=3,841$. Dari hasil uji statistik wald di atas, nilai uji statistik wald pada variabel $\mathrm{X}_{1}$ dan $\mathrm{X}_{5}$ lebih besar dari nilai chi-square tabel, sedangkan nilai variabel $\mathrm{X}_{2}, \mathrm{X}_{3}$ dan $\mathrm{X}_{4}$ lebih kecil dari nilai chi-square tabel. Dari hasil uji wald diatas dapat disimpukan bahwa $H_{0}$ ditolak, ini berarti bahwa hanya variabel $\mathrm{X}_{1}$ dan $\mathrm{X}_{5}$ yang berpengaruh secara signifikan terhadap kepuasan pasien dalam pelayanan Rumah Sakit Umum Daerah Majene.

\section{Uji Kecocokan Model}

\begin{tabular}{|c|c|c|c|}
\hline Step & Chi-square & Df & Sig. \\
\hline 1 & 6,892 & 8 & 0,548 \\
\hline
\end{tabular}

Gambar 6 Hosmer and Lemeshow Test

Nilia Chi-square tabel $=15,51$ dengan $\alpha=0,05$ dan $d f(g-2)=8$, dengan demikian dapat dilihat bahwa,

$$
\hat{C}<\chi_{(\alpha, g-2)}^{2}
$$

yaitu $6,892<15,51$.

\begin{tabular}{|c|c|}
\hline Variabel & $B$ \\
\hline$X_{1}$ & 0,367 \\
\hline$X_{2}$ & $-0,127$ \\
\hline$X_{3}$ & $-0,047$ \\
\hline$X_{4}$ & 0,044 \\
\hline$X_{5}$ & 0,403 \\
\hline Konstan & $-6,892$ \\
\hline
\end{tabular}

Gambar 7 Nilai Koefisien Variabel

Hasil pengujian statistik pada Gambar 6 di atas menunjukkan probabilitas sigifikansi diperoleh angka 0,548 dimana lebih besar dari nilai $\alpha=$ 0,05 sehingga dapat disimpulkan bahwa $H_{0}$ diterima jika tidak ada perbedaan antara observesi dan prediksi, dengan kata lain model fit atau layak untuk digunakan.

\section{Model Regresi Loisitk Biner}

$\ln \left(\frac{\pi(x)}{1-\pi(x)}\right)=-6,892+0,367 \mathrm{X}_{1}-0,127 \mathrm{X}_{2}-$
$0,047 \mathrm{X}_{3}+0,044 \mathrm{X}_{4}+0,403 \mathrm{X}_{5}$

\section{PEMBAHASAN}

Berdasarkan hasil penelitian yang dilakukan terhadap pasien Rumah Sakit Umum Daerah Majene, diperoleh data pasien rumah sakit pada bulan Mei 2017 seperti pada Gambar 1 menunjukkan jumlah pasien Rumah Sakit Umum Daerah Majene pada bulan Mei 2017 sebanyak 443 pasein yang terdiri dari 176 pasien atau 39,73\% yang berjenis kelamin laki-laki dan 267 pasien atau $60,27 \%$ yang berjenis kelamin perempuan. Hal ini menunjukkan bahwa sebagian besar pasien Rumah Sakit Umum Daerah Majene berjenis kelamin perempuan.

Berdasarkan hasil penelitian dengan jumlah sampel sebanyak 100 responden seperti pada Gambar 2 menunjukkan bahwa jumlah responden yang berjenis kelamin laki-laki sebanyak 46 pasien atau $46 \%$ dan sisanya berjenis kelamin perempuan yang merupakan responden terbanyak sebesar 54 pasien atau 54\%. Sedangkan ditinjau dari kelompok usia pasien Rumah Sakit Umum Daerah Majene yang paling dominan adalah kelompok usia 21-30 tahun yakni sebesar 38 pasien atau $41 \%$.

Variabel yang diuji dalam penelitian ini adalah tangibles atau bukti langsung $\left(\mathrm{X}_{1}\right)$, reliability atau kehandalan $\left(\mathrm{X}_{2}\right)$, responsiveness atau daya tanggap $\left(\mathrm{X}_{3}\right)$, assurance atau jaminan $\left(\mathrm{X}_{4}\right)$ dan empathy atau empati $\left(\mathrm{X}_{5}\right)$. Berdasarkan hasil penelitian seperti pada Gambar 3 menunjukkan bahwa secara simultan variabel tangibles atau bukti langsung $\left(\mathrm{X}_{1}\right)$, reliability atau kehandalan $\left(\mathrm{X}_{2}\right)$, responsiveness atau daya tanggap $\left(\mathrm{X}_{3}\right)$, assurance atau jaminan $\left(\mathrm{X}_{4}\right)$ dan empathy atau empati $\left(\mathrm{X}_{5}\right)$ bersama-sama memberikan kontribusi secara signifikan terhadap kepuasan 
pasien sebesar 18,1\% dengan nilai ketetapan prediksi sebesar $74 \%$.

\section{DAFTAR PUSTAKA}

[1] Aisyah Nur. Regresi Logistik dan Penerapannya dalam bidang kesehatan. Universitas Islam Negeri Sunan Kalijaga: Yogyakarta. 2010.

[2] Albana Madjid. Aplikasi Regresi Logistik Ordinal untuk menganalisis tingkat kepuasan pengguna jasa terhadap pelayanan di Stasiun Jakarta kota. Skripsi Universitas Pakuan. Jakarta, 2009.

[3] Atmawati Ruskita, Wahyuddin. Analisis Pengaruh kualitas pelayanan terhadap kepuasan konsumen pada matahari departemant store di solo grand mall. Jurnal pascasarjana Universitas Muhammadiya. Surakarta, 2003.

[4] Edward Gagah P.T. Analisis Kepuasan Konsumen Terhadap Kualitas Pelayanan Jasa Kesehatan.Jurnal penelitian12 No. 1. Jakarta, 2011.

[5] Garson, G.D. Logistik Regression. Dipublikasikan di http:/www2.chass.ncsu.edu/garson/PA765 /logistic.htm(11 Juli 2012), 2008

[6] Halidah. Pemodelan Regresi logistik dalam penentuan faktor-faktor yang berpengaruh terhadap penyakit jantung koroner.Jurnal sains dan matematika19 No. 3 (2011): h. 91-95.

[7] Handayani Rachmat. Penerapan Metode Regresi logistik dalam menganalisis adopsi teknologi pertanian. Jurnal Penelitian pengkajian dan pengembangan teknologi pertanian. Semarang, 2014.

[8] Jacoeb AM, Purwaningsih S, Rinto. Pengaruh kualitas pelayanan terhadap kepuasan pengguna jasa pada RSUD Bangil Kab. Pasuruan. Jurnal Ketsa Bisnis01 No 1 ( Agustus 2014).

[9] Kurniawan, Deny. Regresi Linier (Linear Regression): Forum Statistika, 2008.

[10] Kusmana.Model regresi logistik biner stratifikasi pada partisipasi ekonomi perempuan di provinsi Jawa Timur. Jurnal sains dan seni pomits 3 No. 1 (Edisi 2014).
[11] Luknis Sabri, Sutanto H.S. Statstik Kesehatan. Jakarta: PT. Raja Grafindo Persada.2006.

[12] Lupioadi, Rambat, Hamdani. A.Manajemen Pemasaran Jasa. Jakarta: PT. Selemba Empat. 2006. Hal.

[13] Moenir, H.A.S. Manajemen Pelayanan Umum di Indonesia. Jakarta: PT. Bumi Aksara. 2006.

[14] Rinduwan, Sunarto. Pengantar Statistik untuk penelitian pendidikan, sosial, ekonomi, komunikasi dan bisnis. Alfabeta:Bandung, 2009. Hal 68

[15] Utomo Setyo. Model Regresi Logistik untuk menunjukkan pengaruh pendapatan per Kapita, Tingakat Pendidikan, 